\section{Composites}

Research
Vol.27, No. 3, 83-89 (2014)

DOI: http://dx.doi.org/10.7234/composres.2014.27.3.083

ISSN 2288-2103(Print), ISSN 2288-2111(Online)

Paper

유리섬유와 열전도성 첨가제가 함유된 PBT 수지의 기계적 물성거동에
미치는 열충격피로의 영향

김기수* * 최낙삼**† . 박상대***

\title{
Thermal Shock Fatigue Influence on Mechanical Property Behavior of PBT Resin Embedded by Glass Fibers and Thermal Conductive Particles
}

\author{
Ki-Soo Kim*, Nak-Sam Choi**†, Sang-Dae Park***
}

\begin{abstract}
The purpose of this study is to improve the strength and thermal conductivity of polybutylene terephthalate (PBT) by embedding various additives. Specimens were prepared using PBT pellets embedded with glass fibers (GF) and boron nitride (BN) powders. The test results showed that tensile strength decreased, and thermal conductivity increased with increasing BN contents. with thermal shock cycles conducted, unfilled PBT showed a considerable decrease in failure strain and strength, whereas strength and thermal conductivity of glass fiber and BN particle-embedded PBT had little differeces. With increasing BN, the thermal conductivity of PBT composites was highly improved.
\end{abstract}

초 록: 본 연구는 엔지니어링 플라스틱인 Polybutylene terephthalate(PBT)에 첨가물을 넣어 강도와 열전도성, 열충 격 내구성을 개선시키는 것을 목적으로 한다. 그에 따라 PBT에 유리섬유(Glass Fiber)와 Boron nitride(BN)을 복합 적으로 첨가하여, 각각의 조성비에 따른 기계적 특성과 열전도 특성변화를 실험적으로 분석하였다. 시험 결과 $\mathrm{BN}$ 의 함유량이 증가함에 따라 열전도도는 증가하였고, 기계적 강도는 작아졌다. 열충격싸이클을 가한 결과, 비충전 $\mathrm{PBT}$ 는 파단 신장률이 작아졌으나 충전 $\mathrm{PBT}$ 는 강도와 열전도율이 별다른 성질변화가 거의 없었다. $\mathrm{BN}$ 의 첨가에 따라 PBT 복합재의 열전도도도는 크게 향상되었다.

Key Words: Polybutylene terephthalate, Boron nitride, 유리섬유(Glass fiber), 복합재료(Composite materials), 열충격 (Thermal shock), 열전도도(Thermal conductivity), 기계적특성(Mechanical property)

1. 서 론

플라스틱은 고가공성, 경량, 저가의 특성을 갖는다. 가정 용품에서부터 기계, 건설, 자동차, 항공 등의 산업용품을 위 한 부품을 위하여 광범위하게 널리 사용되고 있으며, 계속
적으로 그 수요 역시 빠르게 증가하고 있다. 플라스틱은 열 과 전류에 대한 절연성을 가지고 있는 것에 반하여 보통 금 속에 비해 약한 강도특성으로 인해 용도가 한정되어 있는 것이 현실이다. 그러나 산업기술의 발전과 함께 특수한 성 질을 갖는 고기능 플라스틱의 요구가 증대되고 있으며, 고

Received 4 December 2013, received in revised form 11 June 2014, accepted 18 June 2014

*한양대학교 대학원 기계메카트로닉스 공학과

***한양대학교 기계공학과, Corresponding author (E-mail: nschoi@hanyang.ac.kr)

***N.N science 책임연구원 
분자 접목 기술의 발전과 함께 특수한 용도에서 요구되는 특성을 만족시키는 엔지니어링 플라스틱에 대한 개발이 최 근 활발히 수행되고 있다[1-5].

엔지니어링 플라스틱은 구조용 및 기계부품용 재료에 적 합한 플라스틱으로서 기계부품, 전기/전자 부품 등의 가공 을 위하여 다방면으로 사용되고 있다. 그 중 Polybutylene terephthalate(PBT)는 다른 엔지니어링 플라스틱에 비해 결 정화 속도, 유동성 및 성형성이 우수할 뿐만 아니라, 인장 강도, 내화학성, 내마모성, 절연성이 우수하여 여러 산업분 야에서 널리 사용되고 있는 반면에, 우수한 열전도 특성을 요구하는 분야에서는 사용되기 어려웠다. 열등한 열전도성 을 개선하여 열전도 능력이 요구되는 산업분야에 플라스 틱재료의 사용을 확대할 필요가 있는 것이다. 이것은 플라 스틱에 열전도성 입자를 첨가하여 원하는 기계적 강도 및 열전도성을 가지도록 하는 것이다. 또한 고온 다습한 환경 에서 사용되는 온도센서 하우징 등의 소재로서 적용되기 위해서는 열전도도가 우수하여야하며 환경노화에 내구성 을 가져야 한다. 이를 위해 기계적 강도 특성이 우수한 Polybutylene terephthalate(PBT)를 모재로 선정하였으며, 강 도를 더욱 높이기 위해 유리섬유(Glass fiber, GF)를 첨가하였 고 열전도 특성을 높이기 위해 boron nitride $(\mathrm{BN})$ 를 첨가하였 다(BN의 열전도도 $30 \mathrm{~W} / \mathrm{m}^{\circ} \mathrm{K}[6] . \mathrm{PBT}$ 의 분자쇄의 구조는

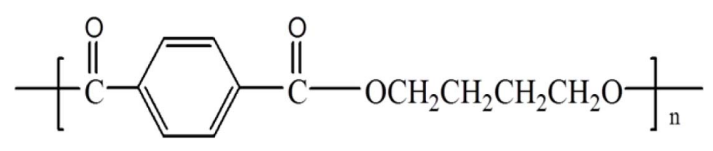

이다. 짧고 두꺼운 체인과 얇고 긴 체인이 에스테르 결합으 로 연결되어 있고 부분적으로 다발형태로 되어 있어, PBT 성형품들은 강성이 뛰어나며 마모가 적다. 또한 유리섬유 와의 복합효과가 뛰어나, 강성의 향상이 용이하다. 또 전기 적특성이 온도변화나 습도변화에 영향을 덜 받는다[7-12].

본 연구에서는 이처럼 우수한 PBT에 유리섬유(Glass Fiber, $\mathrm{GF})$ 와 Boron nitride(BN)를 복합적으로 첨가하여, 각각의 조 성비에 따른 기계적 특성과 열전도성, 동탄성해석(Dynamic Mechanical Analysis, DMA)[13]을 실험적으로 분석하였 다. 또한 본 소재의 내구성시험을 위해 열충격사이클을 준 시편과 그렇지 않은 시편을 각각 준비하여 기계적, 열적 실 험을 수행하여 내구성 변화를 분석하였다.

\section{2. 실 험}

\section{1 시편 제작 및 가공}

본 논문에서 모재로 사용한 Polybutylene terephthalate (PBT)는 필렛타입의 순수한 비충전 $\mathrm{PBT}$ (코오롱플라스틱, $\mathrm{KP} 211 \mathrm{Bl}$ ), 유리섬유(glass fiber, GF)가 $15 \mathrm{wt} \%$ 함유된(코오 롱플라스틱, $\mathrm{KP} 213 \mathrm{G} 15 \mathrm{Bl}$ ) 2종의 필렛소재로 추가적인 처 리 없이 필렛 상태로 사용되었다. 또한, 첨가제로서 사용된
붕화질소(Boron nitride, $\mathrm{BN}$ )은 순도 $99.0 \%$, 입자 크기 0.65 1.1 $\mu \mathrm{m}$ 파우더 형태의 재료(셀모코리아, BN for china) 이다. 필렛형태의 PBT 수지(GF0 wt\%, GF15 wt\%)와 파우더 형태의 $\mathrm{BN}$ 을 Table 1에 제시된 조성비에 따라 총 8 종의 혼 합비로 혼합한 후, Twin blade 믹서에 투입하여 $250^{\circ} \mathrm{C}$ 에서 $7 \mathrm{rpm}$ 으로 블렌딩(Blending)하여 압출기를 통해 압출 후 상 온에 냉각하여 각종 성형에 용이한 약 $5 \mathrm{~mm}$ 크기의 필 렛 형태의 복합수지를 제작하였다. 그 후 소형 사출기와 금형 을 이용하여 Fig. 1에 보여지는 바와 같이 KSM3006 2호 덤 벨형 인장 시편[14]으로 제작하였다.

이 시편을 이용하여 Fig. 2에 보이는 각종 평가 시험을 위

Table 1. Specimen kinds

\begin{tabular}{c|c|c}
\hline \multicolumn{2}{c|}{ Filler content (wt\%) } & \multirow{2}{*}{ PBT (wt\%) } \\
\hline \multirow{4}{*}{ Glass fiber } & Boron nitride & 100 \\
\cline { 2 - 3 } 0 & 0 & 90 \\
\cline { 2 - 3 } & 10 & 80 \\
\cline { 2 - 3 } & 20 & 70 \\
\hline \multirow{5}{*}{15} & 30 & 85 \\
\cline { 2 - 3 } & 0 & 75 \\
\cline { 2 - 3 } & 10 & 65 \\
\cline { 2 - 3 } & 20 & 55 \\
\hline
\end{tabular}

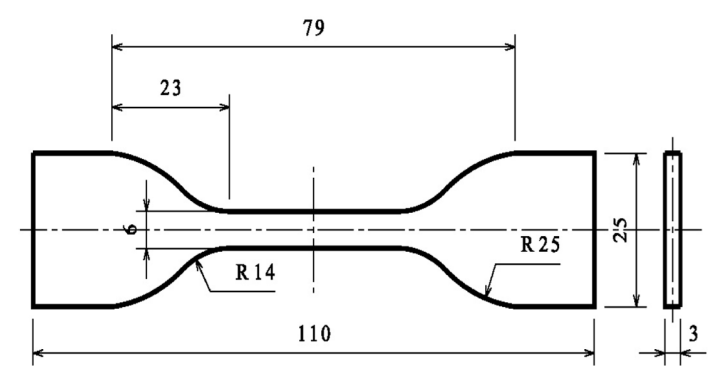

Fig. 1. Geometry of tensile test specimen (unit : $\mathrm{mm}$ )

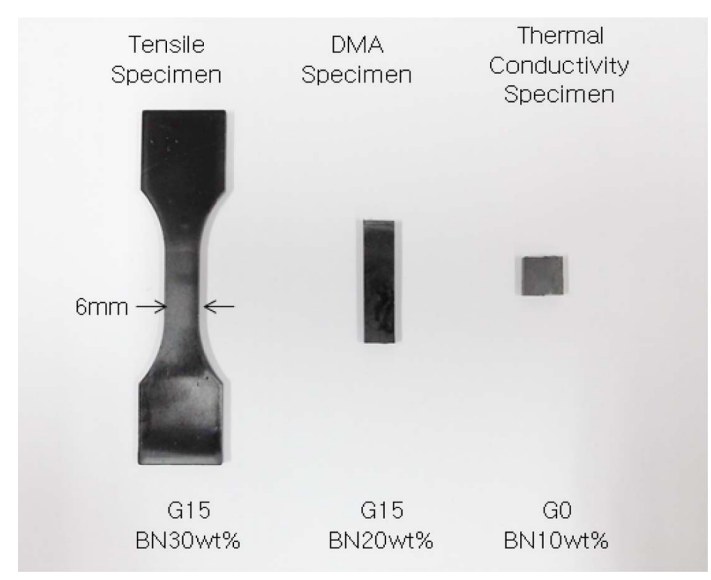

Fig. 2. Examples of the various specimens 


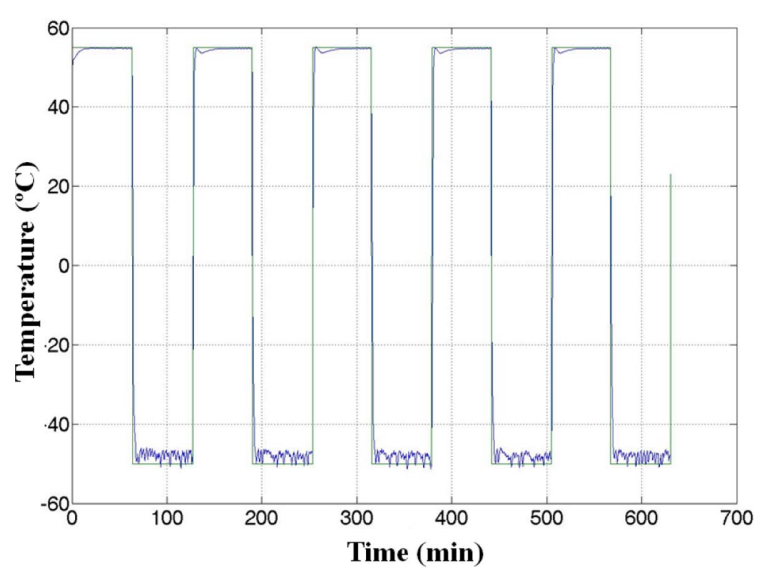

Fig. 3. Thermal shock cycles used

한 시편들을 추가적인 가공을 통하여 획득하였다. DMA 시 편은 인장시험편의 양 끝 면을 다이아몬드 커터로 절단하 여 게이지부분에서 가로 $17.5 \mathrm{~mm}$ 세로 $8.5 \mathrm{~mm}$ 두께 $5 \mathrm{~mm}$ 이하의 시편을 가공하여 사용하였다.

열전도도 시편은 인장시험편의 게이지부분을 $10 \mathrm{~mm} \times$ $10 \mathrm{~mm}$ 크기로 가공절단 후 $5 \mathrm{~mm}$ 두께를 갖는 시편을 제작 하였다.

\section{2 시험 방법}

온도 변화에 의한 소재의 기계적 내구성 거동을 관찰하 기 위하여 앞서 제작된 각종 시편에 열충격테스트를 수행 하여, 각 조성비의 시편에 열충격을 반복하여 가했다. 열충 격시험(VT7012S3, Votsch사)은, Fig. 3에 제시한 바와 같이 60 분 동안 $-50^{\circ} \mathrm{C}$ 의 저온 상태를 유지한 후 $+55^{\circ} \mathrm{C}$ 까지 온도 를 급속히 상승시켜 다시 60 분간 유지 시키는 과정을 총 5 사이클 반복하였다. 이 열충격 조건은 Mil-Std-883 Method 1010[15]에 소개된 공업용 플라스틱의 열충격 내구성 시험 조건에서 저온조건을 인용하였고 고온조건은 가정용 가전 제품류에 적용될 수 있는 상한 온도를 참고하여 정하였다.

앞서 준비된 시편에 대하여 재료의 기계적 강도특성을 관찰하기 위하여 만능재료시험기(Zwick, z250)을 사용해 인 장시험을 수행하였다. 인장 시험시 사용되는 시편은 KSM3006 2 호형 덤벨시편이며, $1 \mathrm{~mm} / \mathrm{min}$ 의 부하속도를 유지하여 시 편에 인장 부하를 가하였다.

$\mathrm{DMA}$ 시험기(Q800, TA Instruments)를 이용하여 재료의 저장탄성계수(Storage modulus)와 손실탄성계수(Loss modulus) 그리고 유리전이온도(Glass Transition Temperature, $\mathrm{T}_{\mathrm{g}}$ )와 $\tan \delta$ 값을 측정하였다. 측정온도 범위는 상온 $25^{\circ} \mathrm{C}$ 에서 $180^{\circ} \mathrm{C}$ 까지 측정하였으며 승온 속도는 $3^{\circ} \mathrm{C} / \mathrm{min}$ 이고 시편에 인가 된 주파수는 $1.0 \mathrm{~Hz}$ 이다.

열전도도시험은 열전도도측정기(Laser Flash Apparatus $457, \mathrm{NETZCH}$ 사)를 사용하여 수행하였다. 비열(표준 시편 을 기준으로 측정)과 밀도를 구하여 열확산도(a), 열전도도

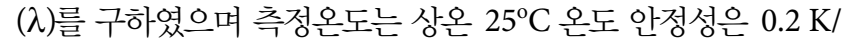
$\min$ 이었다. $\mathrm{BN}$ 첨가물의 분포도를 분석하기 위하여 시편 표피를 폴리싱하여 주사전자현미경(Scanning electron microscope, SEM)을 통해 관찰하였다.

\section{3. 결과 및 고찰}

Fig. 4는 비충전한 PBT 사출시편(GF0 wt\%)과 PBT에 GF15 $\mathrm{wt} \%$ 와 $\mathrm{BN} 30 \mathrm{wt} \%$ 을 혼합한 사출 시편의 인장하중-변위 그 래프이다. 비충전 시편의 경우 변위 $1.5 \mathrm{~mm}$ 이후 서서히 항 복신장을 하다 변위 $8 \mathrm{~mm}$ 이후 넥킹(Necking)이 발생된 후 변위 $28 \mathrm{~mm}$ 에서 파단이 발생하였다. 그에 반해 $\mathrm{GF} 15 \mathrm{wt} \%$ $\mathrm{BN} 30 \mathrm{wt} \%-\mathrm{PBT}$ 시편은 급격하게 높은 기울기를 보이며 탄 성영역상태에서 파단이 되는 것을 볼 수 있다. 이로써 비충 전 $\mathrm{PBT}$ 는 연성이 아주 높으며 $\mathrm{BN}$ 을 첨가하여 탄성계수가 커지고 취성적이 됨을 확인할 수 있다.

Fig. 5는 비충전 PBT에 대해 열충격피로 전과 후의 인장 하중-변위 그래프이다. 열충격피로 전과 열충격피로 후에 그래프 모두 동일하게 연성적으로 천천히 증가하다가 항

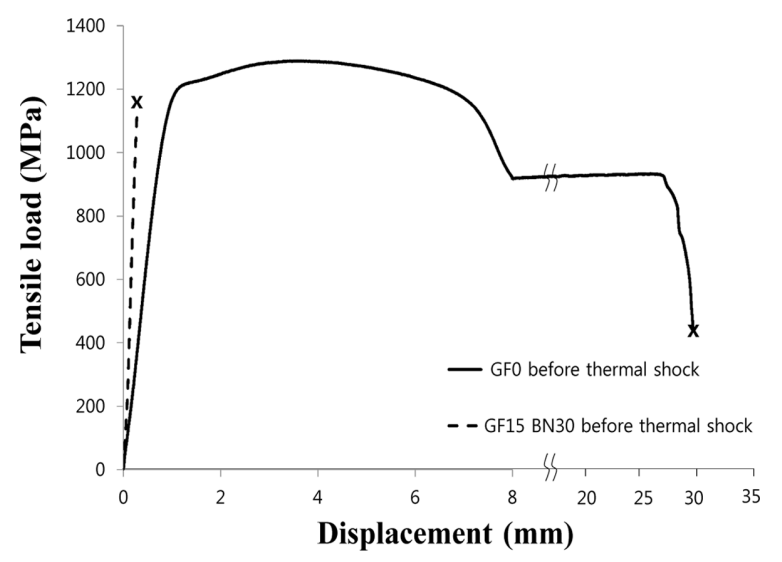

Fig. 4. Tensile behaviors of unfilled PBT and glass fiber $15 \mathrm{wt} \%$ \& BN30 wt\%-PBT specimens before thermal shock

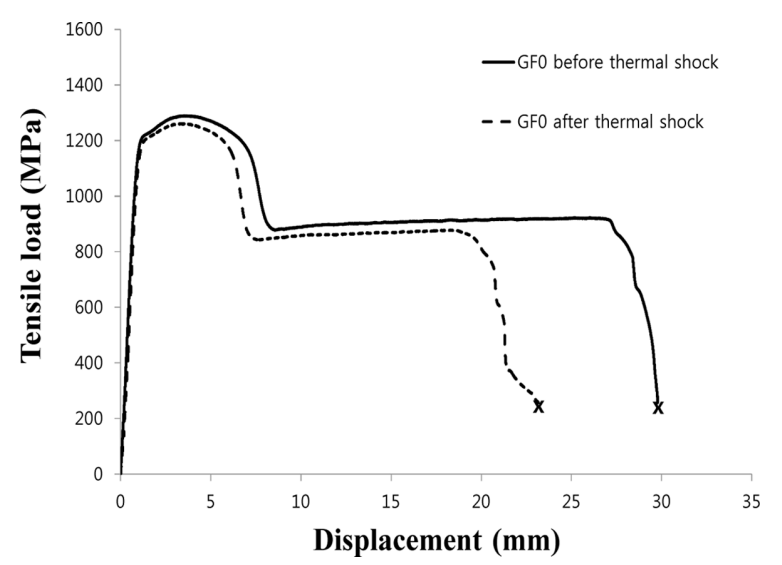

Fig. 5. Tensile behaviors of unfilled PBT before and after thermal shock cycles 
복점과 하항복점이 나타나는 항복현상을 보였다. 하지만 열충격피로에 의해 상항복의 거동이 다소 단축되고 강도 와 파단점이 상당히 감소하여 다소 취성적으로 변질되었다.

Fig. 6은 GF15 wt\% BN30 wt\%-PBT 시편의 열충격피로 전 과 후의 인장하중-변위 그래프이다. Fig. 5의 비충전 PBT와

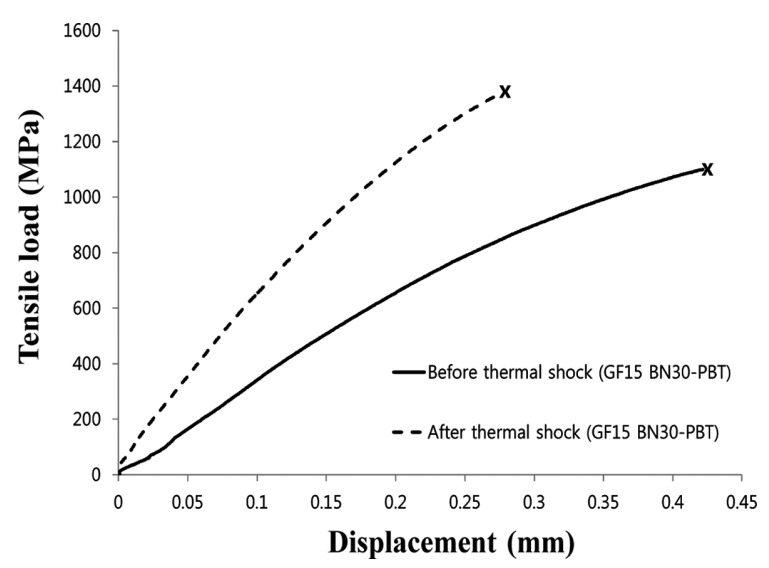

Fig. 6. Tensile behaviors of GF15 wt $\%$ BN30 wt\%-PBT before and after thermal shock cycles

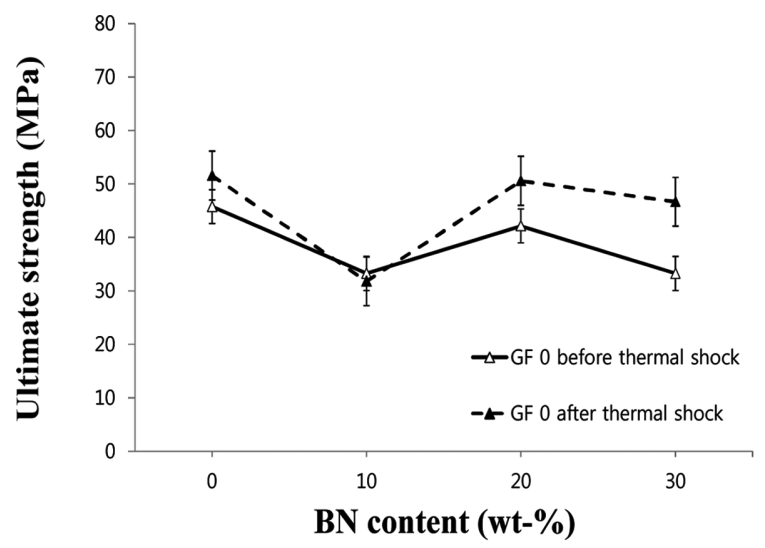

(a)

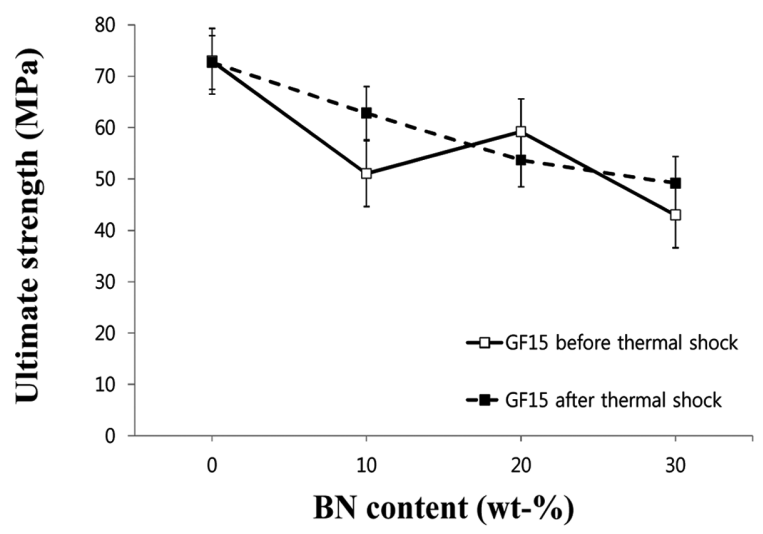

(b)

Fig. 7. Ultimate strength vs. BN contents for glass fiber $0 \mathrm{wt} \%$ (a) and glass fiber $15 \mathrm{wt} \%$ (b)
는 다르게 항복신장과 네킹거동이 보이지 않고 거의 선형 적으로 탄성변형이 진행되다가 소성영역으로 넘어가면서 파단이 일어났다. 또한 열충격피로를 가한 시편은 인장강 도가 커졌으나 파단시 신장률은 감소하였다. 이 결과를 통 해 열충격피로시험의 영향이 본 소재에 대해 상당히 컸음 을 알 수 있다.

Fig. 7(a)와 (b)는 유리섬유가 미 첨가된 시편과 첨가된 시 편에 대한 각각의 $\mathrm{BN}$ 함유량에 따른 인장강도 그래프이며, 각각 열충격피로시험 전후의 인장시험 결과를 비교하여 나 타내었다. 두 그래프 모두 $\mathrm{BN}$ 함유량이 증가함에 따라 인 장강도가 감소하는 경향을 알 수 있다. 또한 열충격피로시 험 후에는 전반적으로 인장강도가 증가되는 경향을 보였 으니 $\mathrm{BN} 20 \mathrm{wt} \%$ 에서는 오히려 다소 작아지는 예외적인 경 우도 발생했다.

한편, $\mathrm{GF} 15 \mathrm{wt} \%$ 의 경우에는 $\mathrm{BN}$ 함유량이 증가함에 따른 인장강도의 저하정도가 $\mathrm{GF0} \mathrm{wt} \%$ 보다 더 크게 나타났다. 그 이유로서 $\mathrm{BN}$ 은 입자 상태로 분산되어 함입되어 있고 $\mathrm{BN}$ 입자와 PBT 사이에 계면에서 충분한 접착상태가 되어 있 지 않기 때문에 $\mathrm{BN}$ 입자의 증가에 따라서 계면부의 박리 와 함께 초기 균열이 발생하기 쉬워서 강도저하가 컸던 것

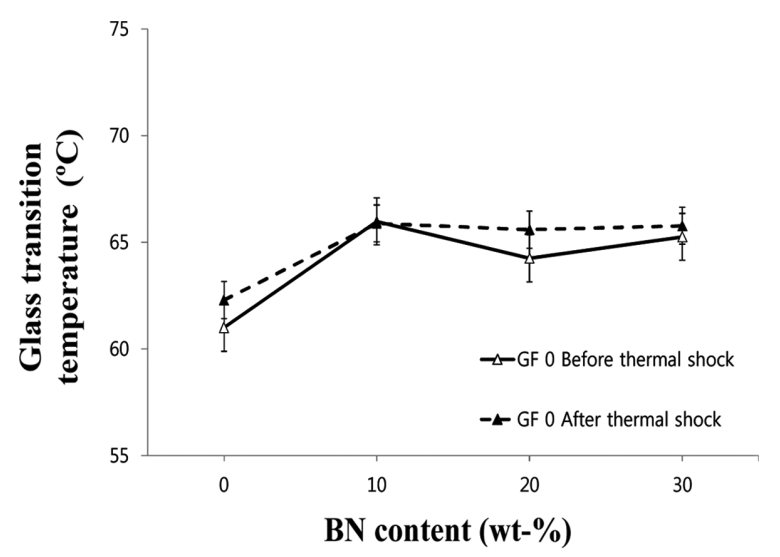

(a)

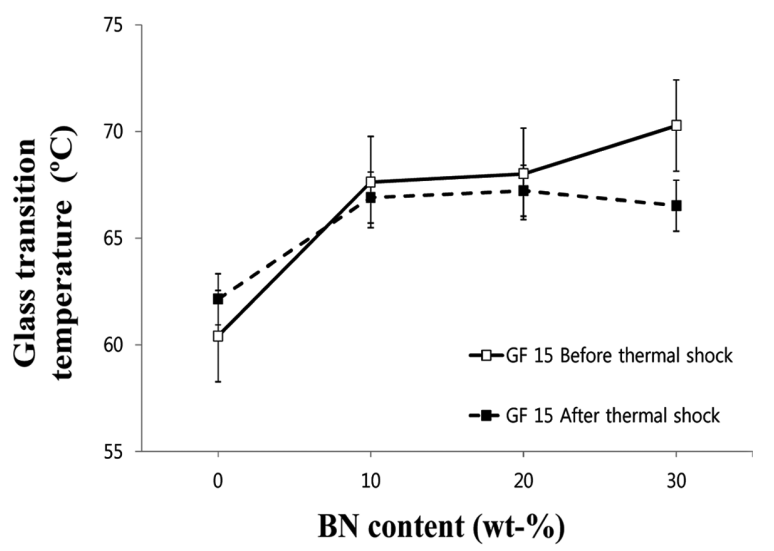

(b)

Fig. 8. Glass transition temperature vs. BN contents : (a) glass fiber $0 \mathrm{wt} \%$, (b) glass fiber $15 \mathrm{wt} \%$ 
으로 생각된다. 그러나 열충격피로에 따른 강도의 변화경 향은 GF0 wt\%처럼 명확하게 일어나지 않았다.

Fig. 8(a), (b)는 각 시험편에 대하여 $\mathrm{BN}$ 함유량에 따른 유 리전이온도를 비교한 값이다. $\mathrm{BN}$ 함유량의 증가에 따라 유 리전이온도는 $\mathrm{BN} 10 \mathrm{wt} \%$ 까지 $5^{\circ} \mathrm{C}$ 이상의 확실한 증가를 보 였으나 그이상의 $\mathrm{BN}$ 함유량에서는 추가적인 증가가 보이 지 않았다. 하지만, 열충격피로시험에 의해 유리전이온도 의 뚜렷한 증감효과를 일관성 있게 확인할 수 없었다.

Fig. 9는 BN 함유량에 따른 GF0 wt\%-PBT (a), GF15 wt\%$\mathrm{PBT}(\mathrm{b})$ 의 저장탄성률의 변화를 나타낸다. $\mathrm{BN}$ 의 함유량이 늘어날수록 시편의 탄성률이 증가하였다. 비충전 PBT의 경 우 열충격피로에 의해 저장탄성률이 다소 증가하였음에도, $\mathrm{BN}$ 과 $\mathrm{GF}$ 의 함유에 의해 열충격피로 효과는 각 조성비에 서 약간씩 다르게 나타났다.

$\mathrm{GF} 15 \mathrm{wt} \%$ 가 함유된 $\mathrm{PBT}$ 수지에 $\mathrm{BN}$ 이 각각 $20 \mathrm{wt} \%$ 와 $30 \mathrm{wt} \%$ 첨가된 경우가 탄성계수 측면에서 우수하였으며, 이 경우에는 열충격 효과가 저장탄성률을 오히려 약간 감 소시켰다.

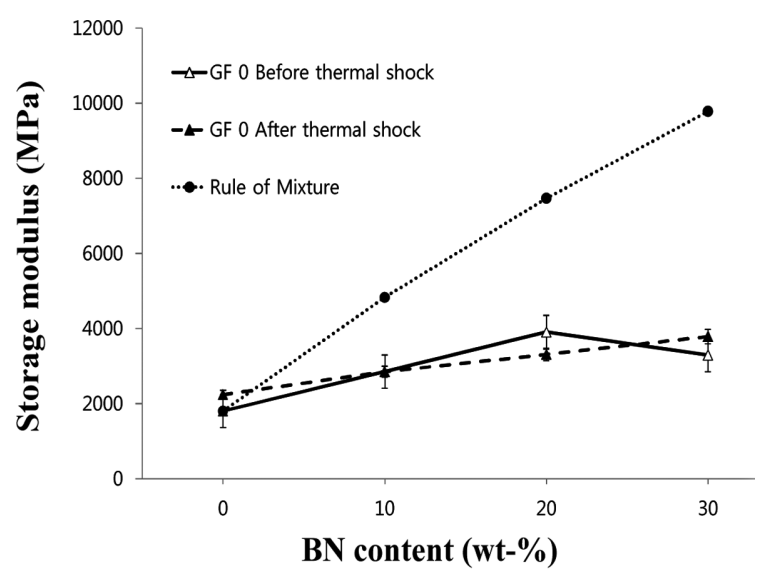

(a)

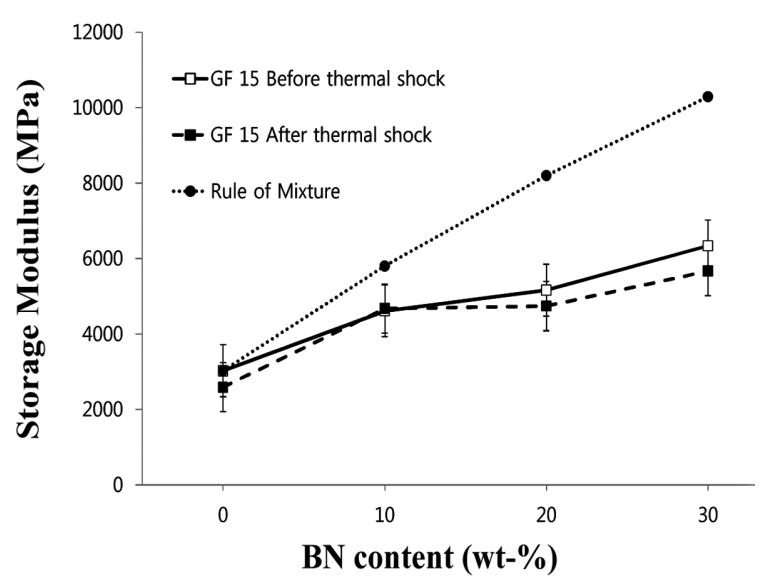

(b)

Fig. 9. Storage modulus vs. BN contents: (a) glass fiber 0 wt $\%$, (b) glass fiber $15 \mathrm{wt} \%$
한편 저장탄성률은 $\mathrm{BN}$ 함유량의 증가에 따라 거의 선형 적으로 증가하므로 혼합물 법칙(Rule of mixture)에 따를 것 으로 예상한다. 충전물의 부피분률 $V_{F}$ 는

$$
V_{F}=\frac{m_{F} / \rho_{F}}{m_{F} / \rho_{F}+M_{m} / \rho_{m}}
$$

이다. 여기서, $m_{F}$ 는 첨가재의 질량분률, $M_{m}$ 은 모재의 질량 분률, $p_{F}$ 는 첨가재의 비중, $p_{m}$ 은 모재 비중이다. 같은 방식 으로 $V_{m}$ 을 구하면 복합재의 탄성률 $E_{c}$ 는 혼합물 법칙

$$
E_{c}=V_{f} E_{f}+V_{m} E_{m}
$$

이다. 여기서 $E_{f}$ 는 충전물의 탄성계수, $E_{m}$ 은 모재의 탄성계 수이다. Fig. 9에서 가는 점선은 혼합물법칙에 의해 계산된 탄성계수 결과를 나타내는데, 문헌[6]에서 소개된 $\mathrm{BN}$ 의 탄 성계수 $(46.9 \mathrm{GPa})$ 를 기초로 구한 것이다. 실험값은 혼합법 칙의 예상 값보다 $\mathrm{BN}$ 함유율이 클수록 작아졌으며, 이는 실제 사용된 $\mathrm{BN}$ 입자 탄성계수가 문헌값 보다 현저히 낮 았음을 의미하였다. $\mathrm{BN}$ 분말은, 구형이 아닌 불규칙하고 날

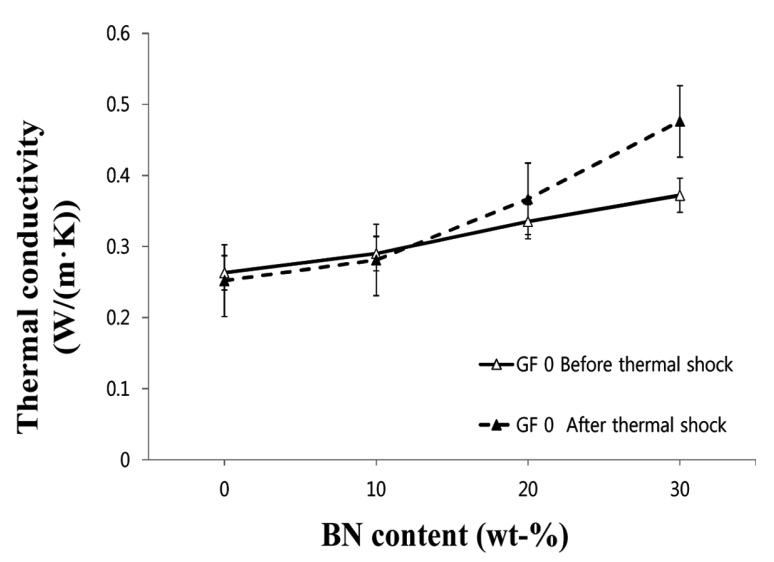

(a)

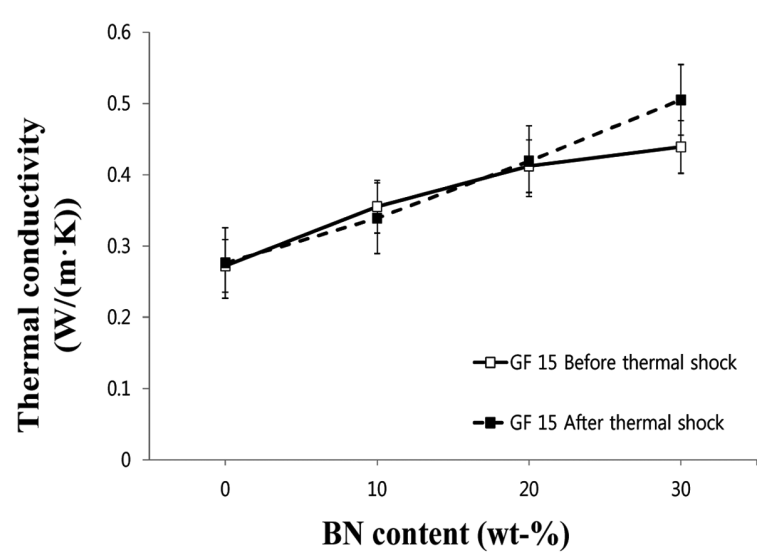

(b)

Fig. 10. Thermal conductivity vs. BN contents: (a) glass fiber $0 \mathrm{wt} \%$, (b) glass fiber $15 \mathrm{wt} \%$ 
카로운 3차원 입자이므로 응력집중원이 많아져 저탄성계 수를 유발할 가능성이 높으며, 또한 $\mathrm{BN}$ 분말을 가공시에 $\mathrm{BN}$ 입자에 많은 결함이 생성되어 원소재 $\mathrm{BN}$ 의 탄성률보 다 훨씬 열등하게 변했을 가능성이 있다.

Fig. 10(a)와(b)는 BN 함유량에 따른 각각 GF0 wt\%-PBT, $\mathrm{GF} 15 \mathrm{wt} \%-\mathrm{PBT}$ 의 열전도도를 나타낸다. 시편에 첨가된 $\mathrm{GF}$ 는 열전도도에 별 영향을 미치지 않는 것으로 판단된다. 그 리고 두 경우 모두 $\mathrm{BN}$ 함유량의 증가에 따라 열전도도가 거의 선형적으로 증가한다는 점에서, 혼합물법칙(Rule of mixture)을 따르고 있음을 보였다. 하지만 Fig. 9에서와 유 사하게 혼합물 법칙에 의하여 이론적으로 계산한 결과는 실제 실험값보다 과대하였다.

이러한 결과는 $\mathrm{PBT}$ 와 $\mathrm{BN}$ 의 블렌딩 시 $\mathrm{BN}$ 의 입자가 균일 하게 분산되지 않아 구조적인 차이가 발생하였고 이론값 의 계산에 사용한 $\mathrm{BN}$ 의 열전도도의 값이 제작사에서 제공 한 값과 차이가 있어 발생한 것이라 사료된다. 더욱 정확한 결과를 얻기 위해서는 현재 사용된 $\mathrm{BN}$ 입자에 대한 열전 도도 측정 시험이 수행되어 혼합물 법칙에 대입하기 위한 정량적인 데이터의 확보가 필요하다고 판단된다.

Fig. 11(a)와 (b)는 각각 열충격 전과 후에 GF15 wt\% BN30

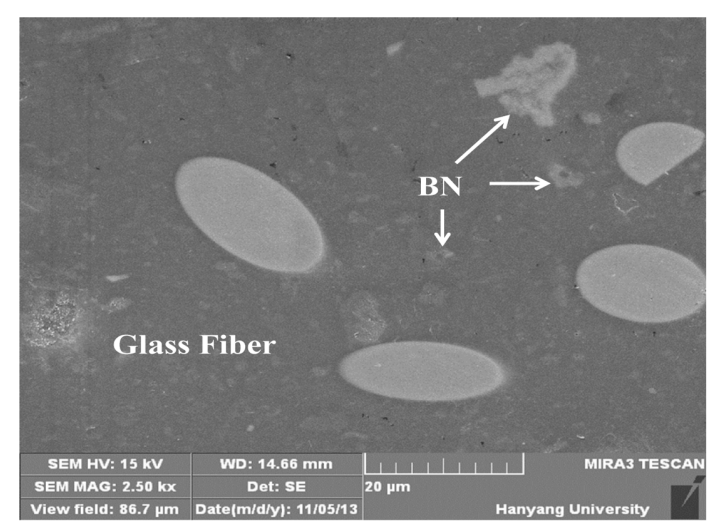

(a)

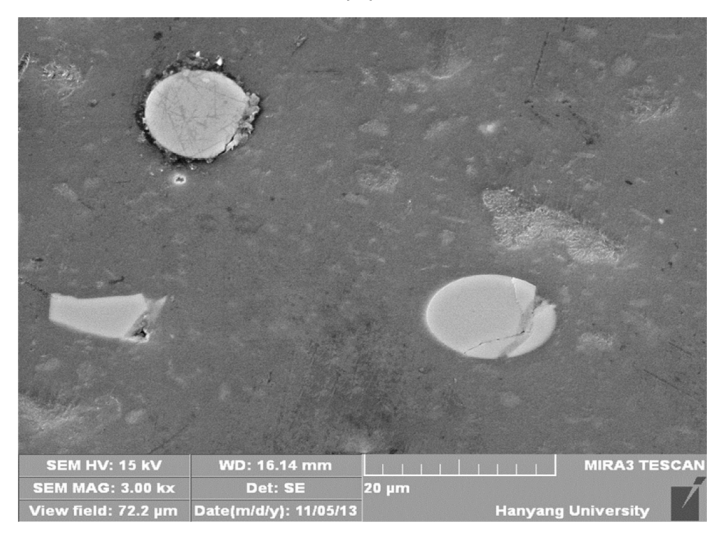

(b)

Fig. 11. SEM Images of the specimen: (a) glass fiber $15 \mathrm{wt} \%$ before thermal shock, and (b) glass fiber $15 \mathrm{wt} \%$ BN30 wt $\%$ after thermal shock
wt\%-PBT 시편의 게이지 표면을 주사전자현미경(Scanning electron microscope, SEM)으로 관찰한 사진이다. 두 사진 모 두 $\mathrm{PBT}$ 와 $\mathrm{BN}$ 이 잘 혼합되어 있었으나, $\mathrm{BN}$ 입자의 형상과 크기가 매우 불규칙하고 편차가 큼을 알 수 있었다. 그러나 열 충격을 준 시편(b)에서는 유리섬유 계면부에서 부분적 으로 계면박리(Debonding)가 관찰되기도 하였다. 그 이유 는 열충격 피로하중을 받으면서 섬유와 모재의 열팽창계 수에 차이가 큼으로 유리섬유의 끝단에서 응력집중이 일 어나 계면박리가 발생하였기 때문이다. 그 이외에는 열충 격을 준 시편(b)과 그렇지 않은 시편(a)간의 별다른 차이는 보이지 않았다. 계면박리는 phonon에 의한 열전달을 방해 하게 되지만 계면박리가 국부적으로만 나타나 $\mathrm{BN}$ 함량에 따른 열전도율의 증가거동자체에는 큰 저해요인이 되지 못 하였다.

\section{4. 결 론}

본 연구는 에어컨, 비데, 정수기 등과 같은 고온 다습환 경에서 사용되는 센서의 하우징에 사용가능한 고분자 열 전도성 플라스틱의 개발을 위해 수행한 것이다. 온도센서 의 하우징에 사용되는 플라스틱은 기본적으로 전기절연도 와 열전도도가 우수하여야 하며 환경노화에 강인한 특성 을 가져야 한다. 이를 위해 내마모성 및 강도특성이 우수한 고분자 플라스틱인 Polybutylene terephthalate(PBT)를 모재 로 하였으며, 이에 강도가 우수한 유리섬유(glass fiber, GF) 와 함께, 열전도성이 우수한 Boron nitride(BN)를 복합적으 로 첨가하여 모재의 기계적 특성을 개선하였다. 선택된 모 재와 첨가재의 혼합조성에 따른 기계적 특성 변화를 정량 적으로 평가하고 각 조성에 따라 시편을 준비하여, 평가하 였다. 그 결과는 다음과 같다.

유리섬유를 미 첨가한 $\mathrm{PBT}$ 와 첨가한 $\mathrm{PBT}$ 에 $\mathrm{BN}$ 을 첨가 하면 인장강도가 감소함을 확인하였다. 또한, 같은 $\mathrm{BN}$ 함 유량에서 유리섬유 첨가시 인장강도가 증가하였다. 유리전 이온도는 $\mathrm{BN}$ 함유량에 따라 유리섬유를 첨가한 시편이 미 첨가한 시편에 비하여 다소 증가하였다. 열충격피로시험 후 인장강도는 유리섬유 미 첨가 $\mathrm{PBT}$ 에서 모두 증가하였 으나, 유리섬유 함유시에는 열충격피로 효과가 거의 발생 하지 않았다. 또한, 유리전이온도는 유리섬유 첨가에 의해 서 유리전이온도가 다소 높아지고 열충격피로에 의한 변 화는 뚜렷하지 않았다. 열전도도는 $\mathrm{BN}$ 함유량의 증가에 의 거 복합칙만큼에는 미진하였으나 뚜렷이 증가하였으며 열 충격피로효과는 별로 개선되지 않았음을 확인하였다.

\section{후 기}

본 연구는 중소기업기술혁신개발사업/기업부설연구소지 원사업의 지원으로 수행된 것이며, 이에 감사드립니다. 


\section{참고문헌}

1. Oh, S.Y., "PET/PBT of Characteristics and Technology Development Trend," Journal of the Korean Society for Polymer Science and Technology, Vol. 3. No. 2, April, 1992.

2. Lu, X., Xu, G., Hofstra, P.G., and Bajcar, R.C., "MoistureAbsorption, Dielectric Relaxation, and Thermal Conductivity Studies of Polymer Composites," Journal of Polymer Science Part B: Polymer Physics, Vol. 36, 1998, pp. 2259-2265.

3. Ng, H.Y., Lu, X., and Lau, S.K., "Thermal Conductivity, Electrical Resistivity, Mechanical, and Rheological Properties of Thermoplastic Composites Filled With Boron Nitride and Carbon Fiber," Polymer Composites, Vol. 26, 2005, pp. 66-73.

4. Alexandre, M., and Dubois, P., "Polymer-layered Silicate Nanocomposites: Preparation, Properties and Uses of a New Class of Materials," Materials Science \& Engineering R-Reports, Vol. 28, No. 1-2, 2000, pp. 1-63.

5. Wilkinson, A.N., Tattum, S.B., and Ryan, A.J., "Melting, Reaction and Recrystallization in a Reactive PC-PBT Blend," Polymer, Vol. 38, No. 8, 1997, pp. 1923-1928.

6. http://accuratus.com/boron.html
7. Utacki, L.A., “Commercial Polymer Blends", 1996, pp. 175-176.

8. Binsack, R., Rempel, D., Humme, G., and Ott, K.-H., US Patent, No. 4, 1981, 292, 233.

9. Binsack, R., Rempel, D., Lindner, C., and Morbitr, L., US Patent, No. 4, 1985, 535, 124.

10. Wang, I., US Patent, No. 4, 1988, 753, 986.

11. Crosby, J.M., "Recent Advances in Thermpplastic Composites", Advanced Materials \& Processes, Vol. 133, No. 3, 1988, pp. 5659.

12. Muzzy, J.D., and Kays, A.O., "Thermoplastic vs Thermosetting Structurla Composites," Polymer Composites, Vol. 5, No. 3, 1984, pp. 169-172.

13. Yang, J.S., Lee, K.-Y., Choi, Y.S., Choi, J.-C., Park, D.-H., and Park, D.-H., "Modulds and Fractural Side Measurement of Semiconductive Shied (Materials) in Power Cable Using the DMA," Journal of the Korean Institute of Electrical and Electronic Material Engineers, Vol. 6, 2005, pp. 213-214.

14. Korean Standard, "Determination of Tensile Properties of Plastics," ks M 3006.

15. Mil-Std-883 Method 1010. 